\title{
Investigating the impact of TPACK development course on pre-service science teachers' performances
}

\author{
İdris Aktaş ${ }^{1}$ (D) Haluk Özmen ${ }^{2}$
}

Received: 13 February 2020 / Revised: 21 October 2020 / Accepted: 22 October 2020 / Published online: 18 November 2020

(c) Education Research Institute, Seoul National University, Seoul, Korea 2020

\begin{abstract}
The aim of this study is to investigate the Technology Pedagogy and Content Knowledge (TPACK) development of preservice science teachers (PSTs) who participated in a TPACK Development Course (TPACK-DC) that consisted of three stages: a training course, lesson plans involving the application of micro-teaching, and school application. This study was carried out with six PSTs selected according to the appropriate sampling method. Semi-structured interviews, lesson plan reports, and video recordings of lesson presentations were used to follow the development of PSTs. At the end of the study, it was found that TPACK-DC contributed to the association of PSTs' Technological Knowledge (TK), Pedagogical Knowledge (PK), and Content Knowledge (CK), which eliminated deficiencies in these areas of knowledge, as well as in the understanding of TPACK. The TPACK-DC also promoted the use of information and communication technology (ICT) tools by PSTs. It helped to develop the knowledge required to choose suitable teaching methods using technology to teach the related subject matter, teaching said content correctly, applying skills to promote active participation by students, proper classroom management, and applying appropriate guidance while teaching science subjects with ICT tools.
\end{abstract}

Keywords TPACK development $\cdot$ Training course $\cdot$ Micro-teaching $\cdot$ School applications $\cdot$ Performance-assessment

\section{Introduction}

The effective use of educational technologies in teaching has become an important issue that educators have focused on in recent years. Researchers have used various methods, such as a five-stage computer technology integration model (Toledo 2005), systemic planning model (Wang and Woo 2007), pedagogy, social interaction, technology generic model (Wang 2008), and e-Capacity model (Vanderlinde and Braak 2010) for the integration of technology and instruction. One of the methods used for the integration of technology in teaching is the Technology Pedagogy and

Electronic supplementary material The online version of this article (https://doi.org/10.1007/s12564-020-09653-x) contains supplementary material, which is available to authorized users.

İdris Aktaş

idrisaktasdr@gmail.com

1 Department of Elementary Teacher Education, Amasya University, Milli Hakimiyet Kampüsü, Eğitim Fakültesi, Merkez, Box 05000, Amasya, Turkey

2 Department of Mathematics and Science Education, Trabzon University, Trabzon, Turkey
Content Knowledge (TPACK) model proposed by Mishra and Koehler (2006).

\section{The nature of TPACK construct}

TPACK does not have an agreed upon theoretical definition. TPACK is most commonly defined by researchers as a seven-dimensional model of knowledge types, which consist of Technology Knowledge (TK), Content Knowledge (CK), Pedagogical Knowledge (PK), and the intersection of these knowledge types (TPK, TCK, PCK) into TPACK (Mishra and Koehler 2006). However, some researchers define TPACK as a unique type of knowledge that emphasizes the concept of a central TPACK component beyond these seven components (Angeli and Valanides 2009). TPACK is generally defined as the basic knowledge that teachers require for effective teaching with technology and the theoretical framework of the application of this knowledge (Mishra and Koehler 2006; Niess 2005). Mishra and Koehler (2006) define the seven-dimensional TPACK concept as follows: CK is the subject knowledge that teachers teach, which includes central concepts, facts, and processes related to the content. PK is the knowledge of concepts that develops in the minds of 
students, the skills necessary for learning, how students will structure the knowledge, and how students will be motivated to learn. TK is the knowledge involved in using ICT tools, such as a computer, software programs, and technological tools in business and daily life. PCK is the knowledge relating to the consideration of students' characteristics when teaching subject matter knowledge. TPK is the knowledge of understanding the effects of technologies appropriate to pedagogical strategies geared toward learning and teaching environments and knowing how to strengthen students' learning without content knowledge. TPC is the knowledge related to the use of technologies in presenting, applying, or researching subject knowledge. Finally, TPACK is the knowledge at the heart of the model; that is, understanding how to use appropriate technologies to support the learning of content presented through specific pedagogical strategies. TPACK sets out the theoretical framework of the model for the knowledge that teachers/pre-service science teachers (PSTs) should have when integrating teaching and technology, as well as how to apply this knowledge.

\section{Literature review about TPACK development strategies}

After examining studies conducted on TPACK during the early years, it is seen that researchers focused on defining the concepts of TPACK (Cherner and Smith 2017; Mishra and Koehler 2006; Niess 2005; Swallow and Olofson 2017) and determining the relationships between the concepts (Ay et al. 2015; Lin et al. 2013; Tondeur et al. 2017). Later, researchers moved on to determining the perceptions and competencies of PSTs regarding TPACK using existing measurement tools and developing new ones (Akyuz 2018; Hechter 2012; Jen et al. 2016; Lee and Tsai 2010; Lin et al. 2013; Redmond and Lock 2019; Schmidt et al. 2009; Tokmak 2013; Yeh et al. 2015, 2017). In recent years, researchers have focused on the development of TPACK in PSTs using various strategies, such as lesson plans, training courses, lesson presentations, peer coaching, and real-class experience (Cheah et al. 2019; Dalal et al. 2017; Jang 2010; Jang and Chen 2010; Koh and Divaharan 2011; Lee and Kim 2014; Lu and Lei 2012; Özgün-Koca et al. 2011; Tseng et al. 2019; Valtonen et al. 2015).

Koh and Divaharan (2011), who aim to identify and improve PSTs' understanding of TPACK have found that they do not have enough TPACK and do not fully understand the link between CK, PK, and TK. For this reason, researchers have focused on TPACK development of PSTs. The researchers have aimed to increase TPACK levels in PSTs using various methods, such as preparing and presenting TPACK-based lesson plans (Akyuz 2018; Agyei and Keengwe 2014; Chai and Koh 2017; Chai et al. 2010; Dalal et al. 2017; Koh et al. 2017; Tokmak 2013; Tseng et al.
2019), training and preparing lesson plans (Brinkley-Etzkorn 2018; Özgün-Koca et al. 2011; Koh and Divaharan 2011; Niess 2005), training and preparing lesson plans, and presenting them using micro-teaching methods (Durdu and Dağ 2017). On the other hand, Jang (2010) and Jang and Chen (2010) suggested that peer coaching will lead to TPACK development in cooperative studies. Cheah et al. (2019) and Lu and Lei (2012) also tried to achieve TPACK development in PSTs using TPACK-based lesson presentation in real classrooms. Finally, Lee and Kim (2014) examined TPACK development in PSTs with a model that included information education, micro-teaching, and school applications by considering the advantages and disadvantages of previous methods. However, none of these methods were concrete enough for PSTs who did not have an adequate understanding of TPACK to improve their development (Lu and Lei 2012; Voogt et al. 2013; Yeh et al. 2014). This evidence shows that the studies conducted to increase TPACK and its associated application levels in PSTs is not sufficient, as these problems still exist in associating and applying TPACK. In other words, there is still a need for studies to increase the TPACK and practice levels of PSTs to train teachers with twenty-first century qualifications.

In the last 15 years, researchers have examined the effect of using certain technologies (Koh and Divaharan 2011; Lee and Tsai 2010), specific subject matter areas (Irmak and Y1lmaz-Tüzün 2019), or specific teaching methods (Guzey and Roehrig 2009; Maeng et al. 2013) in developing the understanding of TPACK by PSTs. There are even studies focusing on the impact of certain technologies and specific teaching methods on the development of PSTs' TPACK levels (Valtonen et al. 2015). However, while PSTs might have a high level of TPACK regarding a specific subject, technology, or method, they can have a low level with others. Therefore, focusing on a specific topic, technology, or pedagogical methodology does not yield realistic results when defining the TPACK development of PSTs. For this reason, that focusing on the TPACK applications of PSTs on several subjects, technologies, and teaching methods will provide more accurate results.

\section{TPACK development course to strengthen TPACK levels of pre-service teachers}

When the methods used in the studies aiming to improve the TPACK levels of PSTs were examined as a whole, it showed that the methods which contributed the most to PSTs' TPACK development were preparing technologysupported lesson plans (Akyuz 2018; Dalal et al. 2017; Tseng et al. 2019), preparing lesson plans and presenting them to faculty peers (Chai et al. 2010; Koh et al. 2017; Tokmak 2013), making collaborative plans and presenting them with peer coaching (Jang 2010; Jang and Chen 
2010), training involving the use of ICT tools and presenting TPACK-based lessons (Özgün-Koca et al. 2011; Koh and Divaharan 2011; Niess 2005), and teaching in a real classroom. However, when these methods are examined individually, it is evident that, although PSTs gain knowledge about combining TPACK concepts in technologysupported lesson plans, they cannot compensate for their lack of experience in effectively communicating the ideas included in these plans (Voogt et al. 2013). It is also not enough to gain experience in a real classroom environment when PSTs present TPACK-based lessons to their faculty peers (Yeh et al. 2014), and to accept and use new technology when they make these real classroom presentations (Lu and Lei 2012).

On the other hand, the researchers who have conducted deep analyses on the TPACK development of PSTs have found that they operate their technology-supported lessons as teacher-centered although they plan it as student centered (Angeli and Valanides 2005; Swallow and Olofson 2017). This means that they make students passive listeners when they use technology in their lessons (Yeh et al. 2015), as they change the variables in the simulations themselves and instead of the students (Graham et al. 2009). Besides, one of the issues identified in the literature that continues to be a problem is that PSTs do not reflect theoretical knowledge in a real classroom environment and/or do not perform the desired level of teaching by joining in with each other although they have sufficient knowledge most of the time (Angeli and Valanides 2005; Graham et al. 2009; Niess 2011). When these findings are taken into consideration, it becomes obvious that new strategies need to be used to improve the TPACK levels of PSTs.

Researchers agreed one of the crucial conditions for the TPACK development of PSTs was to engage them the lesson activities (Chai et al. 2010; Jang and Chen 2010; Koh and Divaharan 2011; Lu and Lei 2012; Tseng et al. 2019). Baran et al. (2019) and Tondeur et al. (2019a, b) examined the effect of educational strategies on the TPACK levels of PSTs and concluded that there is a positive relationship between TPACK levels and the notion surrounding the ideal role of educators, comprehension of the importance of technology in education, preparation of lesson plans, participating in peer collaboration, real classroom experience, and continuous feedback. In the present study, to improve the TPACK and application levels of PSTs, considering the advantages of the methods used in previous studies, we propose using a TPACK Development Course (TPACK-DC) consisting of three stages: a training course, lesson plans using a microteaching method, and school applications. The aim of this study is to investigate the impact of TPACK-DC on knowledge and application levels of PSTs. For this general purpose, the research questions are as follows:
(1) What is the impact of TPACK-DC (and each stage of it) on PSTs' understanding of TPACK and its application (and its sub-dimensions) according to the semistructured interview?

(2) What is the impact of TPACK-DC (and each stage of it) on PSTs' understanding of TPACK and its application (and its sub-dimensions) according to lesson plan reports and lesson presentations?

\section{Methods}

\section{Research model}

This study was conducted as a case study that aimed to investigate the TPACK development of PSTs from multiple data sources, which consisted of semi-structured interviews, lesson plan reports, and video recordings of lesson presentations for one year. This study was carried out in the special teaching methods that are taught in the 3 rd year and in the school applications that are taught in the 4 th year of the science teaching program.

\section{Participants}

This study was carried out with six (four females; two males) PSTs selected according to the convenience sampling method. Convenience sampling is a method carried out with participants who are easily accessible for the reliability of the study data (Fraenkel et al. 2012). In this study, convenience sampling was preferred since the participants need to continue working for 1 year and perform specific tasks. TPACK-DC was conducted with 46 (19 males; 27 females) PSTs, but the data of this study were collected from six PSTs. Before the study started, a demographic information questionnaire was applied to all PSTs. Considering the results of the questionnaire and volunteering of the participants, it was determined that two were skillful in PK (PST-4, PST-5), two in TK (PST-1, PST-6), and two in CK (PST-2, PST-3). The average age of these six PSTs was 21 and their ages ranged between 20 and 22 years, and they attended the second semester of the third year of the teacher training program when the study was started. They took several courses for CK, such as physics, chemistry, biology, and pedagogy courses; for PK, they took developmental psychology, science curriculum, teaching methods, and material development; for TK, they took computer courses during previous periods of teacher training program. PSTs had between three and 10 years of experience in office programs, such as Word, PowerPoint, and Internet and computer usage. They only participated in a few lesson presentations. It can be said that PSTs have basic knowledge when it comes to CK, PK, and TK. However, they do not have enough knowledge about 
the TPACK concept, smart boards, simulations, animations, and lesson presentations, except for preparing a PowerPoint presentation for one or two lesson presentations.

\section{Data sources}

In this study, the data collection tools used to follow the development of PSTs were as follows: semi-structured interviews, lesson plan reports, and video recordings of lesson presentations.

\section{Semi-structured interviews}

Semi-structured interviews were conducted four times to follow the TPACK development of PSTs step by step: before the training course, after the training course, after the microteaching lesson plan, and after the real-world school experience. Different and similar interview questions considering the characteristics of each stage were used at the end of the stage. The interview questions were created considering the objectives of the stages. Researchers adapted the questions from the literature and theoretical framework involved with TPACK. The semi-structured interview questions were finalized by taking the opinions of two science educators. The questions are given in Online Appendix 1.

\section{Lesson plan reports}

The PSTs were asked to report their lesson plans and experiences to obtain more detailed information about the lessons and presentations they prepared for the micro-teaching lesson plans and real-world school experience stages. They were given a sample to show how to report their lesson plan based on the ASSURE model in the training course. ASSURE is a model used to provide a structure to plan the learning activities and tools necessary for learning to be effectively achieved by planning the teaching process systematically (Grabinger et al. 2007). PSTs were asked to prepare their lesson plan based on the ASSURE model to make them more effective, efficient, and attractive. They reported their lesson plans and experiences at the end of each presentation.

\section{Video recordings}

The lesson presentations of PSTs were videotaped to follow their TPACK development, to observe their TPACK implementation skills, and to allow them to monitor and evaluate themselves. After their first lesson presentations were videotaped, the PSTs were asked to watch the videotaped carefully and make a second presentation correcting the deficiencies they noted in their presentations. The second presentation made by the PSTs was also videotaped. The video recordings were collected for researchers to analyze at the end of the stage.

\section{Procedure}

The science teacher training program in Turkey consisted of 4 years (eight semesters). This study was carried over 1 year, or two semesters. PSTs first attended the special teaching methods course taught in the second semester of the third year at the Faculty of Education. Then, they attended school lectures taught at the practice school in the first semester of the fourth year. Classrooms at the Faculty of Education have a smart board, internet-connected computers for teachers, mobile desks that can be tailored to the students' work in groups, and one computer for every two students. Classrooms at the practice school have a smart board or computer and projection devices; the school also has a computer laboratory. PSTs implemented their lessons at the practice school either in their classrooms or in the laboratory according to what appropriately fit their lesson plan.

\section{Implementation of the TPACK-DC}

TPACK-DC was implemented in three stages: a training course, lesson plans designed to be used along with microteaching, and school applications. The timeline of the implementation of the three stages is given in Table 1 .

The purpose of each stage of TPACK-DC, the role of the trainer, and PSTs is given in Fig. 1.

The training course includes introducing TPACK concepts and ICT tools to PSTs, such as smart boards, document cameras, animations, and simulations like PHET, developing the skills necessary to use the concepts and tools in science lessons, and trainers presenting sample lesson plans as role models. PHETs are fun, interactive, research-based physical simulations (https://phet.colorado.edu/tr/). At this stage, it is aimed to create TPACK awareness among PSTs, to increase their TK, and to combine TK, PK, and CK. The trainer has two roles: first, to inform PSTs about how to use ICT tools effectively in teaching and second, to set a precedent for PSTs by presenting sample lesson plans. The first trainer made three lesson presentations on the following subjects: "atom and its structure," "electromagnet and transformation of motion energy into electric energy," and "nuclear energy." The trainer used PHET simulation, smart boards, the Internet, videos, and computers as technologybased worksheets for PSTs. Also, the trainer used different teaching techniques such as 5E model, guided inquiry, and argumentation. The trainer did not use only one teaching method or one technology for each subject since this study is based on different methods and technologies that are specific to each subject. The task of the PSTs was to gain an understanding of the convenience of the new ICT tools in 
Table 1 The timeline of the implementation

\begin{tabular}{|c|c|c|c|c|}
\hline Semester/place of implementation & Stage & Duration & Activities & Data sources \\
\hline \multirow{4}{*}{$\begin{array}{l}\text { Second semester of the third year/ } \\
\text { faculty of education }\end{array}$} & \multirow[t]{2}{*}{ Training course } & \multirow[t]{2}{*}{6 weeks } & TPACK concepts were introduced & First semi-structured interview \\
\hline & & & $\begin{array}{l}\text { Smart boards, document cameras, } \\
\text { animations, and simulations, such } \\
\text { as PHET, is interactive science } \\
\text { simulations created by the Uni- } \\
\text { versity of Colorado Boulder, were } \\
\text { introduced } \\
\text { Class discussion was held on how to } \\
\text { effectively use TPACK concepts } \\
\text { First researchers presented example } \\
\text { lesson plans }\end{array}$ & Second semi-structured interview \\
\hline & \multirow{2}{*}{$\begin{array}{l}\text { Lesson plans } \\
\text { involving micro- } \\
\text { teaching }\end{array}$} & \multirow[t]{2}{*}{6 weeks } & \multirow{2}{*}{$\begin{array}{l}\text { PSTs prepared a lesson plan select- } \\
\text { ing a science subject, a technol- } \\
\text { ogy, and a pedagogy method and } \\
\text { presented them to deepen PSTs' } \\
\text { understanding of TPACK and to } \\
\text { gain practical skills }\end{array}$} & $\begin{array}{l}\text { Lesson plan reports } \\
\text { video recordings }\end{array}$ \\
\hline & & & & Third semi-structured interview \\
\hline \multirow[t]{2}{*}{$\begin{array}{l}\text { First semester of fourth year/practice } \\
\text { school }\end{array}$} & \multirow[t]{2}{*}{ School applications } & \multirow[t]{2}{*}{12 weeks } & \multirow{2}{*}{$\begin{array}{l}\text { PSTs experienced lesson presenta- } \\
\text { tions in real classrooms } \\
\text { They made four presentations in real } \\
\text { classrooms }\end{array}$} & $\begin{array}{l}\text { Lesson plan reports } \\
\text { Video recordings }\end{array}$ \\
\hline & & & & Fourth semi-structured interview \\
\hline
\end{tabular}

\begin{tabular}{|c|c|c|c|}
\hline & Training Course & $\begin{array}{c}\text { Lesson Plans } \\
\text { Involving Micro-Teaching }\end{array}$ & School Applications \\
\hline Aim & $\begin{array}{l}\checkmark \text { To raise awareness } \\
\text { about TPACK } \\
\text { concepts } \\
\checkmark \text { To gain the ability to } \\
\text { use ICT tools }\end{array}$ & $\begin{array}{l}\checkmark \text { To gain the ability of to } \\
\text { design lesson plans and using } \\
\text { them by along with the } \\
\text { understanding of TPACK } \\
\text { concepts }\end{array}$ & $\begin{array}{l}\checkmark \text { To develop lesson plans and } \\
\text { practice skills in real classrooms }\end{array}$ \\
\hline $\begin{array}{l}\text { The } \\
\text { role of } \\
\text { the } \\
\text { trainer }\end{array}$ & $\begin{array}{l}\checkmark \text { ICT trainer } \\
\checkmark \text { Being a role model }\end{array}$ & $\begin{array}{l}\checkmark \text { Managing class discussions } \\
\checkmark \text { Providing feedback on } \\
\text { lessons plans and } \\
\text { presentations }\end{array}$ & $\begin{array}{l}\checkmark \text { Giving feedback to PSTs on } \\
\text { lesson plans and presentations }\end{array}$ \\
\hline $\begin{array}{l}\text { The } \\
\text { role of } \\
\text { PSTs }\end{array}$ & $\begin{array}{l}\checkmark \text { Gaining awareness } \\
\text { about TPACK } \\
\checkmark \text { Gaining awareness } \\
\text { about the benefits of } \\
\text { ICT tools for teaching }\end{array}$ & $\begin{array}{l}\checkmark \text { Working collaboratively with } \\
\text { a science teacher and a } \\
\text { student } \\
\checkmark \text { Preparing TPACK-based } \\
\text { lesson plans } \\
\checkmark \text { Making presentations by } \\
\text { applying the micro-teaching } \\
\text { method }\end{array}$ & $\begin{array}{l}\checkmark \text { Working collaboratively with a } \\
\text { science teacher } \\
\checkmark \text { Preparing TPACK-based lesson } \\
\text { plans } \\
\checkmark \text { Making presentations in real } \\
\text { classrooms } \\
\checkmark \text { New lesson plans and new } \\
\text { presentations }\end{array}$ \\
\hline
\end{tabular}

Fig. 1 TPACK development course

the teaching environment and to gain the ability to use these tools. This stage focused on improving the TK of PSTs.

The stage relating to lesson plans involving the application of micro-teaching methods includes the preparation of TPACK-based lesson plans with collaborative studies by PSTs, presentation of these designs, and class discussions. At this stage, the aim was for PSTs to gain the ability to prepare and apply lesson plans by applying their TPACK knowledge. The trainer gave feedback to the PSTs about their lesson plans and presentations and directed class discussions. The task of the PSTs was to prepare a lesson plan by collaborating with a peer and an experienced teacher and then presenting this plan to their classmates using microteaching methods. After the presentation, class discussions 
were conducted in the context of how successful PSTs were in planning the lesson and presenting and what can be done to increase their success. The lesson presentations given by PSTs were videotaped so they could monitor themselves and determine their strengths and weaknesses. PSTs recreated the lesson presentation by arranging the lesson plan in accordance with the video recordings and the feedback they got from class discussions at the end of the presentation. The second stage was completed after collecting video recordings and course plan reports.

School applications included presenting more than one course on different science subjects in real classrooms by PSTs. At this stage, the aim was to provide PSTs with TPACK experience through lesson presentations in real classrooms. The role of the trainer was to provide feedback to the PSTs about their lesson plan. The task of the PST was to prepare the lesson plan, to present it in a real classroom, and to develop their application skills with a new plan and presentation. In this study, each of the PSTs designed and presented four lessons. Lesson presentations were videotaped and collected by one of the researchers, and the course design report was collected the following week.

\section{Data analyses}

\section{Analysis of the data collected from semi-structured interviews}

The data of the semi-structured interviews were analyzed using content analysis. First, two researchers came together to perform content analysis, and they divided it into meaningful sections and coded the data obtained from Pre-Service Science Teacher-1 (PST-1). Then, interviews of the other PSTs were coded separately. After the coding, the consistency of the coding conducted by the researchers was examined. The researchers calculated a measurement of consistency by determining the amount of coded data as different and the same. The measurement of consistency was calculated using the formula: the measurement of consistency $=$ the amount of the same encoded data/(amount of the same encoded data + amount of different encoded data). The results are given in Table 2.

Finally, the data coded differently were re-encoded according to the consensus of the researchers. Coding examples are given in Table 3 .

Table 2 The consistency measurement of semi-structured interview data analysis

\begin{tabular}{lccccc}
\hline PST-1 & PST-2 & PST-3 & PST-4 & PST-5 & PST-6 \\
\hline $\begin{array}{l}\text { Two researchers coded } \\
\text { together }\end{array}$ & 0.849 & 0.906 & 0.874 & 0.885 & 0.912 \\
\hline
\end{tabular}

After the coding, the themes representing a certain TPACK component were brought together, and the themes were created. The frequency of the codes are recorded in Online Appendix 3; the high frequency demonstrates the level of PSTs' understanding of TPACK and its application.

\section{Analysis of data collected from lesson plan reports and video recordings of presentations in a TPACK-based learning environment}

The lesson plans and video recordings of the PSTs' presentations were analyzed together through the rubric of TPACKbased learning environments. Each PST made a total of six presentations: two in the lesson plans involving the application of micro-teaching methods and four in school applications. In total, 36 lesson plans and videos were collected and analyzed. Consequently, lesson plans and videos were reported together through the rubric of TPACK-based learning environments to see the reason for an application the teacher used in the classroom or to see whether an application specified in the lesson plan report was done in the classroom.

The rubric of TPACK-based learning environments is an analytical rubric consisting of 12 performance criteria and five performance levels developed by Aktaş (2015). The researcher created the performance criteria by considering the objectives of the stages adapted from the literature (Koh 2013; Canbazoglu-Bilici et al. 2016) and the theoretical framework of TPACK. Three experts studying in the field of science education were consulted to determine the scope validity of the developed rubric. The rubric of TPACK-based learning environments is given in Online Appendix 2, along with the performance criteria. The rubric emphasizes the concept of the central TPACK component defined by Angeli and Valanides (2009), beyond sub-dimensions. The maximum score of the rubric is 48 , while the minimum is zero. A high score indicates that PSTs' knowledge and application level are above average.

The two researchers came together and scored the lesson plan report and presentation of PST-1 according to the rubric. Then, the data of the other PSTs were scored separately by the two researchers. After the scoring, Kendall's W coefficient was calculated to determine the consistency between the scores of both researchers. Also, Cronbach's alpha coefficient was calculated using the scores of both researchers to determine the internal consistency between the items in the rubric. The results of Kendall's W coefficient and Cronbach's alpha internal consistency coefficient are given in Table 4.

The researchers then met again to compare the scores; the performances scored differently were reviewed and re-scored according to the consensus of the researchers. 
Table 3 Examples of coding of TPACK sub-dimensions

\begin{tabular}{|c|c|c|}
\hline Themes & Codes & Examples \\
\hline \multirow[t]{3}{*}{ TK } & & $\begin{array}{l}\text { Q: What benefit did you get from the course you were given during } \\
\text { the } 12 \text { weeks? What have you gained? }\end{array}$ \\
\hline & Using the smart board & A: I had the opportunity to use the smart board \\
\hline & Understanding office programs (etc. PPT, Word) & $\begin{array}{l}\text { A: I learned about preparing a presentation and creating a video } \\
\text { clip using PPT and similar programs }\end{array}$ \\
\hline PK & Knowing teaching methods & $\begin{array}{l}\text { A: I learned different teaching approaches, such as guided research, } \\
\text { argumentation, and } 5 \mathrm{E} \text {. It was previously described theoretically. } \\
\text { I learned these in a practical way }\end{array}$ \\
\hline CK & Eliminating his/her misconceptions & $\begin{array}{l}\text { A: I was confused about situations in which the work was done and } \\
\text { not done. I learned as a result of our peers' presentations } \\
\text { A: I had some confusion surrounding the naming of compounds }\end{array}$ \\
\hline \multirow[t]{2}{*}{ PCK } & & $\begin{array}{l}\text { Q: What were you concerned about when preparing your lesson } \\
\text { presentation that you made in class? Why so? }\end{array}$ \\
\hline & Considering students' misconceptions in teaching & $\begin{array}{l}\text { A: I first determined the students' misconceptions and chose the } \\
\text { appropriate method to overcome it }\end{array}$ \\
\hline TPK & Using technology to engage students & $\begin{array}{l}\text { A: I used one of the PHET simulations, as it made the students } \\
\text { active in learning. So, almost all students actively attended the } \\
\text { lesson }\end{array}$ \\
\hline TCK & Using technology to exemplify science concepts & $\begin{array}{l}\text { A: I used a simulation via the Internet that showed the move- } \\
\text { ments and temperature of particles when heat was applied to the } \\
\text { substance. I think it was quite appropriate to demonstrate the } \\
\text { concepts surrounding the state of matter }\end{array}$ \\
\hline \multirow[t]{3}{*}{ TPACK } & & $\begin{array}{l}\text { Q: If you prepare a lesson presentation after this course, what do } \\
\text { you care most about? What will you include in your lesson plan? } \\
\text { Why? }\end{array}$ \\
\hline & $\begin{array}{l}\text { Using appropriate technologies facilitating learning to science } \\
\text { subject }\end{array}$ & $\begin{array}{l}\text { A: Since learning is visual in simulation, animation, or PPT, it } \\
\text { attracts the attention of students and allows them to learn about } \\
\text { science concepts more effectively }\end{array}$ \\
\hline & Using technologies activating students while teaching the subject & $\begin{array}{l}\text { A: I find simulations suitable for teaching concepts and preparing } \\
\text { worksheets for students to find the information themselves }\end{array}$ \\
\hline
\end{tabular}

Table 4 The results of Kendall's $\mathrm{W}$ coefficient and Cronbach Alpha internal consistency coefficient

\begin{tabular}{lllllll}
\hline & PST-1 & PST-2 & PST-3 & PST-4 & PST-5 & PST-6 \\
\hline Kendall's W & Two researchers coded together & 0.984 & 0.964 & 0.960 & 0.969 & 0.944 \\
A & & 0.928 & 0.912 & 0.918 & 0.919 & 0.902 \\
\hline
\end{tabular}

In this study, to ensure the reliability of the data, the data were analyzed by two researchers and the consistency coefficient was examined. Also, to ensure validity and triangulation of the data, multiple data collection sources, interviews, video recordings for observation, and lesson plan reports were used. The obtained results were discussed in relation to each other and a conclusion was made.

\section{Findings}

\section{Findings obtained from semi-structured interviews}

In this study, the data of four semi-structured interviews conducted with PSTs to follow TPACK development and reported with content analysis were examined as seven themes: TK, CK, PK, PCK, TPK, TCK, and TPACK. The frequencies for each theme's codes, in which development in the understanding of TPACK occurred in six PSTs, are given in Online Appendix 3. Also, the developments of the TPACK levels of PSTs and its sub-dimensions at each stage of the TPACK-DC are given in Table 5.

Table 5 shows that the training course has mostly improved PSTs' knowledge of PCK, TK, TPK, and TPACK; then TCK; and lastly PK and CK. The lesson plan involving the application of micro-teaching methods mostly developed TPACK, PCK, and TPK; then TCK, TK, and PK; and lastly CK. The school practice mostly developed TPACK, TCK, and TPK; then PCK, and PK; and lastly PCK and CK. As seen in Online Appendix 3, the PSTs stated fewer codes related to TPACK and its components in the preinterviews. Moreover, the frequencies of these codes were 
Table 5 The developments of PSTs' TPACK performance at each stage of the TPACK-DC

\begin{tabular}{llll}
\hline TPACK development & Training course & $\begin{array}{l}\text { Lesson plans involving the applica- } \\
\text { tion of micro-teaching methods }\end{array}$ & School practice \\
\hline Highest developed knowledge & PCK & TPACK & TPACK \\
& TK & PCK & TCK \\
& TPK & TPK & TPK \\
& TPACK & & PCK \\
Medium developed knowledge & TCK & TCK & PK \\
& & TK & TK \\
Least developed knowledge & PK & PK & CK \\
& CK & CK & \\
\hline
\end{tabular}

low. The PSTs had a certain understanding of PK, CK, and TK before the study, and they had little understanding of PCK and TPK, and the understanding of TCK and TPACK were almost nonexistent. In the following interviews, both the number of new codes and the number of PSTs expressing these codes had increased. These findings showed that TPACK-DC increased both the PSTs' understanding of TPACK and their ability to combine TPACK components.

Before the study, most of the PSTs stated that they had PK involving engaging students, drawing students' attention, knowing teaching methods, and making assessments and evaluations. A few PSTs also had an understanding when it came to considering students' knowledge levels, individual differences, and guiding when teaching. Regarding CK, some of the PSTs were intermediate in biology and advanced in physics and chemistry, and some were intermediate in physics and advanced in biology and chemistry. They had TK about using Microsoft Office programs and searching for information on the Internet. Few of the PSTs had PCK about using appropriate concepts for the students' knowledge levels, associating concepts with daily life, conducting appropriate attention-grabbing activities, and considering misconceptions in learning. Few of the PSTs had TPK regarding using visuals in PPT presentation, using technology to facilitate learning and teacher work, and using technology to assess student learning. Few of the PSTs had TCK about exemplifying concepts and had TPACK about using technology with important subject information and visuals and using technologies that are appropriate to the subject and students' level of knowledge.

\section{The effect of the training course stage on PSTs' TPACK}

In the training course, PSTs developed TK about using smart boards, simulations, animations, and document cameras. They developed PK about considering the students' knowledge levels, guiding, and understanding teaching methods. They developed CK about understanding the importance of misconceptions in learning. They developed PCK about choosing effective teaching methods, making assessments, conducting attention-grabbing activities appropriate to the subject, and considering curriculum knowledge and misconceptions. They developed TPK about using technology to engage students, using appropriate technologies for students' levels of knowledge, and guiding students when using technology in lessons. They developed TPK about using technology to research science concepts, using appropriate technology for subject matter, and using technology to access information. They developed TPACK about using appropriate technologies to facilitate learning for specific subject matter, using technologies that will enable students to be active when learning subject matter, and using appropriate teaching methods for the subject matter. Sample statements from the PSTs are as follows:

PST-1: I have learned different teaching approaches. It was theoretically explained before, but now we have learned in practice ... I have learned how to apply them when preparing alternative assessment and evaluation. (PK).

PST-3: Not all methods are suitable for every subject. We need to choose methods according to misconceptions and wherever there is missing information... When using measurement and evaluation techniques, we must apply them to correct the information where there are misconceptions. (PCK).

PST-1: I have learned how to explain a subject combining the relevant technologies and teaching approaches in an appropriate way and use technologies in the classroom to determine how students will learn the subject, that is, how to combine content technology and teaching approaches. (TPACK).

\section{The effect of the lesson plan involving the application of micro-teaching methods stage on PSTs' TPACK}

In the lesson plan involving the application of micro-teaching methods, PSTs practically developed previously gained TK. They developed PK about classroom management, engaging students, drawing students' attention, making 
assessments and evaluations, and guiding students. Few PSTs also have the knowledge that considering students' knowledge levels in teaching and guiding and have developed CK about noticing misconceptions in science subject matter. They practically developed previously gained PCK in addition to gaining new knowledge about engaging students during learning activities and associating science concepts with daily life. They gained TPK about using technology to assess students' learning, using appropriate technologies for students' knowledge levels, using technology appropriate to teaching activities, guiding students when using technology, and using technology to help students to find information. PSTs practically gained knowledge about using technology effectively to reach information in science class besides developing previously gained TCK. They gained TPACK about measuring and evaluating with appropriate technologies for the subject matter, using technologies to draw students' attention to the topic, guiding students when teaching the subject with technology, and using technologies appropriate to the subject and student knowledge level. Sample statements of the PSTs are as follows:

PST-5: ...I can't tell a subject to 7th grade students like I tell 5 th grade... we were only active in the explanation stage of the 5E method. Also, we only guided the students to reach information in the introduction, exploration, or evaluation stage. The students were active in everything else. They studied by themselves for their own learning... (PK).

PST-2: I have learned that we have to choose the appropriate simulations based on the students' knowledge levels instead of using random simulations... We need to choose the appropriate method and technique for the subject and determine the appropriate technologies for this method and technique... (TPACK).

\section{The effect of the school applications stage on PSTs' TPACK}

In the school applications, PSTs practically developed previously gained TK. They gained PK about using time effectively, using language students can understand, providing classroom management, and guiding students when teaching. They practically developed previously gained PCK and gained new knowledge about giving appropriate attention to the subject activities and considering misconceptions when teaching. They practically developed previously gained TPK and gained new knowledge about using images with technologies to improve its memorability and using technology to make the lesson fun and learning easier. They practically developed previously gained TCK and gained new knowledge about using technology to concrete the concepts, using appropriate technology for specific subject matter, and using technology effectively in science lessons. They developed previously gained TPACK and gained new knowledge about choosing the most appropriate technologies to make the concepts of science concrete, choosing teaching methods and technology by considering the pre-learning of the subject matter, using appropriate technologies to facilitate learning in science subjects, and using technologies to enable students to be active and to participate in the lesson when teaching the subject. Sample statements of the PSTs are as follows:

PST-1: I could guess what they could ask, what examples should I give. This has become easier in my next lesson... I tried to lead them to the answer asking questions. It gave me experience, such as giving students tips to reach answers, guiding them (PK).

PST-6: I tried to prepare the lesson design considering the previous knowledge of the students... At first it was really hard for me to get down to student level because I was confused about what concepts I would give and which ones I wouldn't (PCK).

PST-2: I consider that the simulation I will use is suitable for the gain... Students don't get bored when it's visual. The student also understands the subjects better when the concepts are visual. When the simulation is chosen appropriately for the subject matter, there is no confusion in the students' minds. (TCK).

PST-3: I have considered what kind of technologies I can use for the subject matter, how to activate the students... the use of technology and simulations make learning more permanent. Because it is visual in animation, it attracts more attention and enables students to learn more quickly. (TPACK).

\section{Findings obtained from video recordings and lesson plan reports}

\section{The effect of the lesson plan involving the application of micro-teaching methods stage on PSTs' TPACK}

Each of the PSTs made six lesson presentations during the TPACK-DC. The total scores of each presentation obtained from the rubric of the TPACK-based learning environment are given in Graphic 2. Also, the total scores of the PSTs from each item are comparatively given in Graphics 3 and 4 .

When the Graphic 2 is examined, it is clear that TPACK application scores of the PSTs ranged from 33 to 40 in their first presentations in the lesson plan involving the application of micro-teaching methods stage. It can be said that the scores are above mid-level, considering that the highest score that can be obtained from the rubric is 48 (when this score is divided into three equal ranges). Also, the scores of the PSTs in the stage increased (one score in PST-4 and four to five scores in the other PSTs). When Graphics 2 and 


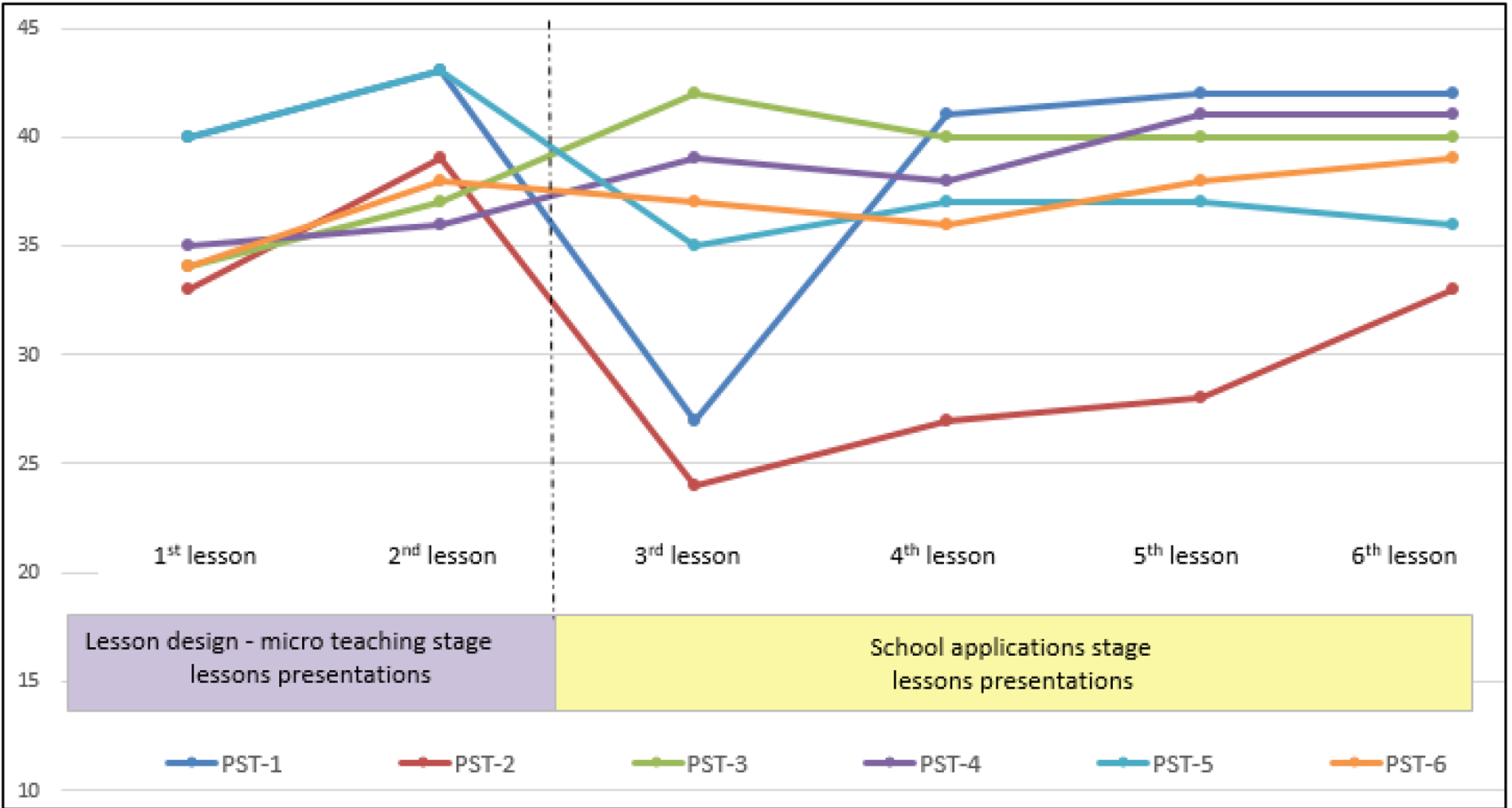

Graphic 2 TPACK developments of PSTs according to TPACK rubric

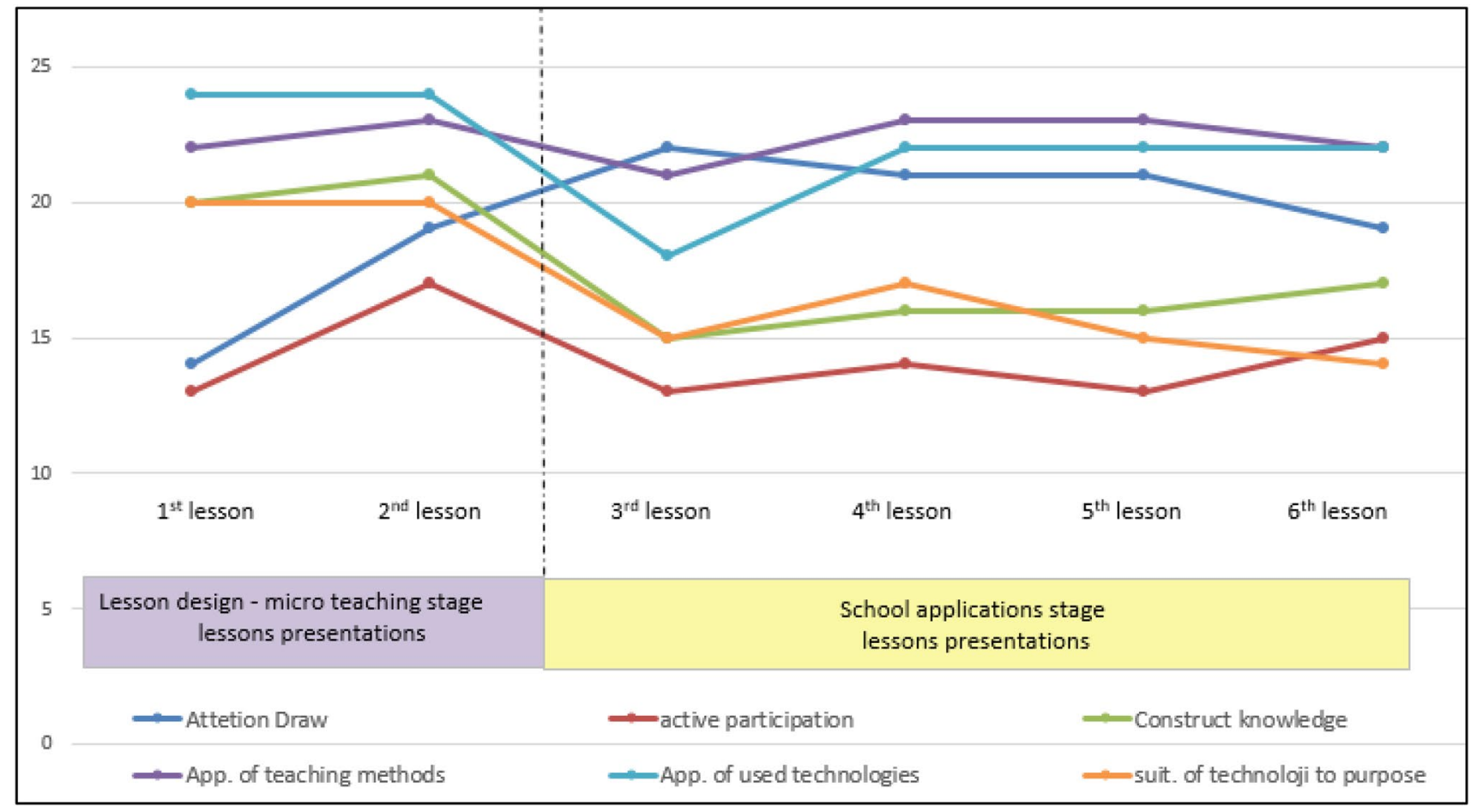

Graphic 3 Total scores of six PSTs from the first six items of the rubric 


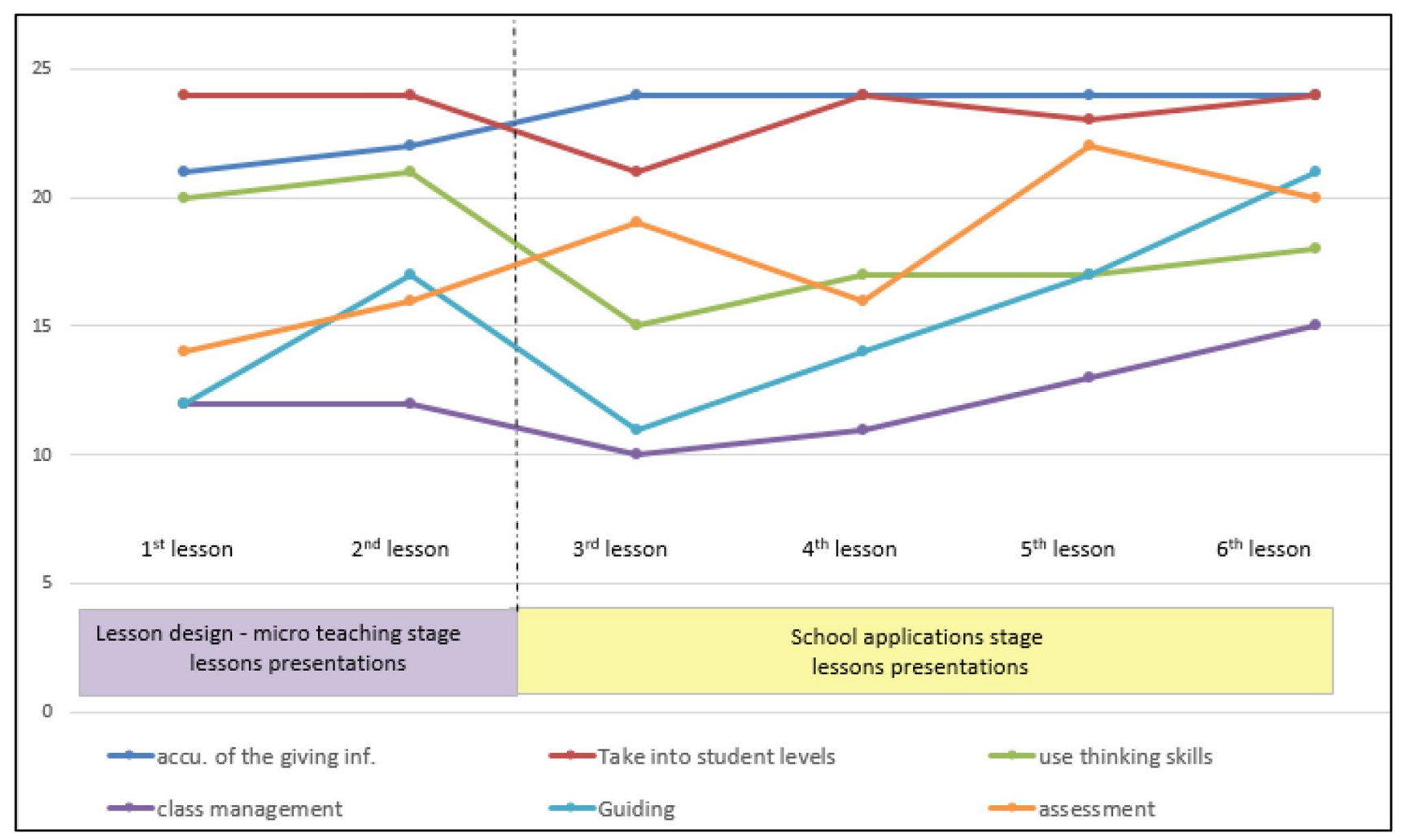

Graphic 4 Total scores of six PSTs from the last six items of the rubric

3 are examined, it is clear that there is an increase in the elements involving drawing students' attention, guiding, ensuring active participation of students, making assessments and evaluations, constructing students' knowledge, appropriateness of chosen teaching methods, the accuracy of the giving information/teaching concepts, and leading students to use higher level thinking skills when teaching science subject matter with technology.

Regarding the guiding item, although the PSTs mostly guided students to understand the concepts by providing worksheets and using the question-and-answer technique by standing in front of the class in the first presentation, they participated in each groups' study for a while to lead them find the information using gestures and mimics and sometimes asking new questions about what, why, and how and sometimes giving tips and feedback in the second presentation. Regarding the providing active participation of students' item, the PSTs tried to engage the students using interactive evaluations or the Internet in most of the course during the evaluation stage besides the beginning stage of the course. Regarding the drawing students' attention item, while the PSTs tried to create a sense of curiosity by asking a few questions about the subject in the first presentation, they started to attract the students' attention with the question-and-answer technique after they presented visuals in a PPT presentation, and sometimes they watched a video in the second presentation. Regarding the making assessments and evaluations item, the PSTs increased their performance to the level of performing alternative assessments for critical objectives in the second presentations, while they made traditional assessments and evaluations for objectives in the initial presentations.

Also, the lesson plan involving the application of microteaching methods stage had a small impact on the items of constructing knowledge of students, appropriateness of chosen teaching methods, the accuracy of the giving information/concepts, and leading students to use higher level thinking skills. On the other hand, it did not affect the items of appropriateness of used technologies and considering students' levels that PSTs had the high performance, and appropriate use of selected technology, and providing class management that PSTs had the low performance in their first presentations. Considering these findings, one can conclude that the lesson plan involving the application of microteaching methods is effective in improving PSTs' TPACK application performance.

\section{The effect of school applications stage on PSTs' TPACK}

When Graphic 2 is analyzed, there is a continuous increase in total TPACK scores of all PSTs. When the total scores of PSTs obtained from each item are examined in Graphics 
2 and 3, the highest increase occurred in the items of guiding and providing classroom management, which had weak performances in initial presentations. According to these findings, it is clear that school application is effective in improving PSTs' TPACK implementation skills, especially guiding and providing classroom management items. On the other hand, there are small declines in the items of drawing students' attention and appropriateness of used technologies when teaching science subjects with technology.

It is noticeable that there are declines in the first two presentations of PSTs', both in the total score and the scores they get from most items when they move from the lesson plan involving the application of micro-teaching methods stage to the school applications stage. In the school applications stage, PST-3 and PST-4 increased their TPACK application levels, PST-5 showed a continuous increase graphic after a decrease in their level, PST-6 and PST-1 showed a regular graphic (except the third presentation), and PST-2 showed a stable graphic after a decrease in its level. When the PSTs' TPACK scores obtained from the lesson plan involving the application of micro-teaching methods stage and the school application stage are compared, it is seen that they are more successful in the items of drawing students' attention, the accuracy of giving information/concepts, and making assessments and evaluations in the school applications, but less successful in other items. It is also seen that the school applications have a more positive effect on the items of guiding, providing classroom management and making assessments and evaluations when teaching science subject matter with technology. According to these findings, it can be concluded that the lesson plan involving the application of micro-teaching methods stage and the school applications stage provide different experiences to the PSTs, so faculty applications cannot predict real classroom practices. On the other hand, the PSTs can, in general, adapt to the real class and show their real performances in the third lesson presentation after giving two lesson presentations.

\section{Discussion}

The findings of this study show that TPACK-DC has many positive impacts on the PSTs' TPACK development levels and all other dimensions. First, it increased TPACK levels by enabling PSTs to associate PK, TK, and CK that they could not associate before the study. Second, it has increased their knowledge and application skills in the items involving engaging students, creating student-centered classroom environments, using appropriate techniques to eliminate the concepts that students have difficulties learning, providing classroom management, and guiding while teaching science with technology. Six possible reasons for this increase in PSTs' TPACK knowledge and application levels of TPACK-DCs are listed below. First, the introduction of technological tools in the training course that PSTs did not encountered before for teaching purposes. Second, the presentation of various sample lessons is planned by the researcher as a model. Third, the class discussions conducted after the lesson presentations provide feedback for the PSTs. Fourth, collaborative studies conducted with experienced science teachers in lesson plan involving the application of micro-teaching methods and school applications stages contribute positively to the PK of the PSTs. Fifth, the researcher encourages the PSTs to use technological tools when teaching with worksheets. And sixth, the PSTs have the opportunity to teach a long-term course of science in different learning areas, both in the faculty and real classroom.

The first two reasons for the increase in PSTs' TPACK development are that they first experienced technological tools, such as smart boards, simulations, and animations in the training course and followed a TPACK-based course presentation in three different science subject matter areas. These reasons are supported by the findings of the interview; that is, most development was revealed in PCK, TK, TPK, and TPACK, then TCK, and lastly PK and CK, in addition to all TPACK knowledge of PSTs after training course. These reasons are also supported by the findings of previous studies that PSTs' TPACK performances in the classroom increased with regard to TK when they were introduced to new technologies (Hechter 2012; Koh and Divaharan 2011; Niess et al. 2009; Özgün-Koca et al. 2011), TCK and TPACK when they received field-specific information training (Graham et al. 2009; Guzey and Roehrig 2009; Jang and Chen 2010; Lee and Kim 2014; Maeng et al. 2013; Niess 2005), TPK and TPACK when they were given sample lesson plans by instructors (Lu and Lei 2012), and TPACK when they gained experienced with ICT tools (Dalal et al. 2017; Chai et al. 2010; Jen et al. 2016; Koh and Divaharan 2011). On the other hand, the fact that the PK and CK of the PSTs were higher than the other TPACK areas before starting the study may be the reason for the least development in this field. There was some improvement in these areas of knowledge, but this increase is lower than the other areas of knowledge.

The other reasons for the increase in PSTs' TPACK development were class discussions after their first presentation and using simulations with worksheets. PSTs' TPACK development influenced the suggestions made by peers in class discussions as the suggestions affected the cognitive structure of the PSTs, and thus, it is an opportunity for the PSTs who considered the suggestions to correct themselves. The findings of this study are consistent with the findings of the previous study that the highest increase in the TPACK levels of the PSTs was realized in the areas of guiding students to access information, ensuring students' active participation (Akyuz 2018; Yeh et al. 2015), making 
complementary assessment for critical objectives (Jang and Chen 2010; Maeng et al. 2013), attracting students' attention with question and answers, and sometimes presenting images in PPT or watching a video (Aktaş 2015) when teaching science subject matter with technology after the class discussions and micro-teaching. Also, these findings were consistent with the findings of Cheah et al. (2019) and Tokmak (2013), which is that teachers and PSTs re-arrange and re-present course presentations and receive pedagogical or technological support that reinforces their TPACK development. In this study, PSTs' use of simulations with worksheets in lesson presentations enabled students to take notes and use technological tools to access information when completing worksheets. This facilitated both the students' participation in lesson activities and the teacher's work. Also, Baran et al. (2019) found out that the most used strategies in TPACK development of PSTs are the trainer as role model and the recognition of the contribution of technology to education, as well as discussing the difficulties encountered and providing experience in technology-supported teaching in the classroom. The findings of Baran et al. (2019) reveal the importance of active participation of the PSTs when presenting the lesson, conducting class discussion, and using worksheets. The researchers stated that the PSTs' TPACK development was positively affected because it provided them with the opportunity to review and generate new ideas that they will use to guide and provide active participation (Jang 2010; Jang and Chen 2010; Lu and Lei 2012) and review lesson designs and consider peer recommendations (Agyei and Keengwe 2014).

The collaboration with an experienced science teacher while preparing lesson plans enabled PSTs to gain information about the student characteristics and making four lesson presentations in real classrooms allowed them to associate TPACK knowledge and to know more about the classroom environment and students. This situation had an impact mostly on the development of the TPACK, TCK, TPK, and then PCK, PK and less TK and CK, besides developing all TPACK knowledge and applications of the PSTs in both lesson design-micro-teaching and school applications. These findings support the rubric findings that PSTs' TPACK has more influenced on total TPACK scores and guiding and classroom management when teaching science with technology. These findings that school applications contributed to the development of PSTs' TPACK performances are consistent with previous study findings (Graham et al. 2009; Lee and Kim 2014; Maeng et al. 2013; Niess 2005). Koehler and Mishra (2009) emphasized that collaborative lesson designs increase TPACK development and it is important for TPACK development to decide on how to select and use technology when teaching a specific topic for a group. Also, Niess (2005) found that PSTs focused on their own teaching in their first lesson presentations, and they did not consider the learning, thinking, and understanding of students; however, they developed themselves over time. The findings that real-class applications are effective on TPACK development of PSTs were supported by the statements of Yeh et al. (2014) and Baran et al. (2019) that only theoretical knowledge is not enough for the TPACK development and real-class experiences should be kept alive.

PSTs began to walk around the classroom, provided classroom management with verbal warnings, and guided students giving hints and feedback to reach information toward the latest presentations when they were teaching in front of the whiteboard, did not interfere to the students engaged in extracurricular activities in the first presentations of school applications. Thus, there has been a shift from teacher-centered presentations to student-centered presentations. These findings have contradicted the finding of Angeli and Valanides (2005) that PSTs used teacher-centered courses using technological tools and materials such as smart board, PPT presentation, simulation, and video although they planned the teaching process as student centered in their lesson plans. In this study, the reason for the student-centered presentation of the PSTs is that they support using technology-based assessments or simulations to teach the subject of science with the worksheets they prepared. In addition, the simulations used by PSTs to teach the science subject are quite suitable for students to reach information. This case created student-centered environments with active participation of students. These reasons are supported by the findings of Maeng et al. (2013) that technology-based tools that enable students to inquiry and explore information facilitate the transition to student-centered teaching. In this study, because this is a long-term study, interpretation of increased PSTs' TPACK development is supported by the findings previously studies that pre-services teachers' classroom management when teaching with technology can only develop with real classroom practices, teachers start making student-centered presentations as they gain experience (Baran et al. 2019; Maeng et al. 2013; Niess 2005). Also, these reasons are supported by the findings that classroom management is the lowest level component in PSTs and their TPACK development increases using educational technologies in real classrooms (Baran et al. 2019; Tondeur et al. 2018, 2019a, b; Yeh et al. 2014).

The originality of this study is that the PSTs collaborated with experienced science teachers, they were encouraged to use the worksheets, and they gained experience in realclass applications in long-term and different subject areas. Experienced science teachers were effective in increasing the PSTs' TPACK levels as they shared their experiences when using the appropriate concepts to the level of students and choosing the appropriate methods and technologies in eliminating the concepts that the students had learning difficulties. The prepared worksheets facilitated the PSTs to 
activate the students, guide them, and provide classroom management as it was prepared to engage students in the science subject and enable them to structure information. Finally, gaining experiences in real-class applications in long-term and different subject areas have been effective to develop TPACK knowledge and practice skills when guiding students to reach knowledge, providing classroom management, particularly TPACK components that enable them to understand the nature of TPACK and integrate TK, PK, and CK.

It should be noted that there are several limitations when interpreting the findings of this study. First, the generalizability of the findings of this study was lower than the random sampling because the participants were selected according to the appropriate sampling method. Second, the lesson designmicro-teaching activities were carried out with the cooperation of two PSTs and one experienced science teacher. These cases may have made the results more positive because PSTs supported and directed each other. Third, the researcher as a trainer encouraged PSTs to conduct lesson presentations through worksheets since the training course. The encouraging role of the researcher as a trainer could be thought as an intervention in the study. Therefore, the findings might be different in studies conducted without the encouraging role of the researcher. In addition, in future studies, following the lesson presentations of the PSTs in their classes when they start their profession will add new findings to the field.

\section{Conclusion}

This study investigated the effect of TPACK-DC on PSTs' TPACK levels, and the following conclusion was reached. TPACK-DC increased PSTs' understanding of TPACK and its application levels in all dimensions. Before the study, it was determined that PSTs' understanding of TPACK concepts and its dimensions was limited, as they were unable to associate the different forms of knowledge with each other and they had deficiencies in the application. Thus, PSTs should have a training course for TPACK development. It is useful to provide a training course, prepare and present lesson plans, conduct class discussions in terms of feedback, have collaboration with experienced science teachers and peers, use technological tools with worksheets, and use longterm real-life application activities to increase TPACK levels of PSTs. Moreover, the use of these activities produces more positive results since each activity contributes to the development of different TPACK areas.

This study also revealed that it is not enough to provide computer or instructional technology courses and teaching methods courses for PSTs to develop their understanding of TPACK and its application. Accordingly, PSTs should be supported with technology-based elective courses that are specific to the field and use ICT tools in their lesson and TPACK development. Further, this study showed that providing TPACK training with all dimensions would be more effective than separating them as technology, pedagogy, and content lessons. Consequently, TPACK-DC, which uses lesson plans involving the application of micro-teaching methods and real-class experiences, has yielded beneficial results in terms of increasing the understanding of TPACK and the associated application skills of PSTs.

\section{Compliance with ethical standards}

Conflict of interest We have no conflicts of interest to disclose.

\section{References}

Aktaş, İ. (2015). Fen bilgisi öğretmen adaylarının teknoloji pedagoji alan bilgisi gelişimlerinin incelenmesi. [Unpublished doctoral dissertation]. Education Science Institute and Karadeniz Technical University, Trabzon, Turkey.

Agyei, D. D., \& Keengwe, J. (2014). Using technology pedagogical content knowledge development to enhance learning outcomes. Education and Information Technologies, 19, 155-171.

Akyuz, D. (2018). Measuring technological pedagogical content knowledge (TPACK) through performance assessment. Computers \& Education, 125, 212-225.

Angeli, C., \& Valanides, N. (2005). ICT-related pedagogical content knowledge: A model for teacher preparation. In C. Crawford, R. Carlsen, I. Gibson, K. McFerrin, J. Price, R. Weber \& D. Willis (Eds.), Proceedings of SITE 2005-society for information technology \& teacher education international conference (pp. 3030 3037). Phoenix, AZ, USA: Association for the Advancement of Computing in Education (AACE). Retrieved August 25, 2019 from https://www.learntechlib.org/primary/p/19585/.

Angeli, C., \& Valanides, N. (2009). Epistemological and methodological issues for the conceptualization, development, and assessment of ICT-TPCK: Advances in technological pedagogical content knowledge (TPCK). Computers \& Education, 52, 154-168.

Ay, Y., Karadag, E., \& Acat, M. B. (2015). The technological pedagogical content knowledge-practical (TPACK-Practical) model: Examination of its validity in the Turkish culture via structural equation modeling. Computers \& Education, 88, 97-108.

Baran, E., Canbazoglu Bilici, S., Albayrak Sari, A., \& Tondeur, J. (2019). Investigating the impact of teacher education strategies on preservice teachers' TPACK. British Journal of Educational Technology, 50(1), 357-370.

Brinkley-Etzkorn, K. E. (2018). Learning to teach online: Measuring the influence of faculty development training on teaching effectiveness through a TPACK lens. The Internet and Higher Education, 38, 28-35.

Canbazoglu-Bilici, S., Guzey, S., \& Yamak, H. (2016). Assessing pre-service science teachers' technological pedagogical content knowledge (TPACK) through observations and lesson plans. Research in Science and Technological Education, 34(2), 237-251.

Chai, C. S., \& Koh, J. H. L. (2017). Changing teachers' TPACK and design beliefs through the Scaffolded TPACK Lesson Design Model (STLDM). Learning: Research and Practice, 3(2), 114-129. 
Chai, C. S., Koh, J. H. L., \& Tsai, C. C. (2010). Facilitating preservice teachers' development of technological, pedagogical, and content knowledge (TPACK). Journal of Educational Technology \& Society, 13(4), 63-73.

Cheah, Y. H., Chai, C. S., \& Toh, Y. (2019). Traversing the context of professional learning communities: Development and implementation of technological pedagogical content knowledge of a primary science teacher. Research in Science \& Technological Education, 37(2), 147-167.

Cherner, T., \& Smith, D. (2017). Reconceptualizing TPACK to meet the needs of twenty-first-century Education. The New Educator, 13(4), 329-349.

Dalal, M., Archambault, L., \& Shelton, C. (2017). Professional development for international teachers: Examining TPACK and technology integration decision making. Journal of Research on Technology in Education, 49(3-4), 117-133.

Durdu, L., \& Dağ, F. (2017). Pre-service teachers' TPACK development and conceptions through a TPACK-based course. Australian Journal of Teacher Education, 42(11), 150-171.

Fraenkel, J., Wallen, N., \& Hyun, H. H. (2012). How to design and evaluate research in education (8th ed.). McGraw Hill: Boston.

Grabinger, S., Aplin, C., \& Brener, P. G. (2007). Instructional design for sociocultural learning environments. Electronic Journal of Instructional Science and Technology, 10(1), 1-16.

Graham, C. R., Burgoyne, N., Cantrell, P., Smith, L., Clair, L., \& Harris, R. (2009). TPACK development in science teaching: Measuring the TPACK confidence of in-service science teachers. Tech Trends Special Issue on TPACK, 53(5), 70-79.

Guzey, S. S., \& Roehrig, G. H. (2009). Teaching science with technology: Case studies of science teachers' development of technology, pedagogy, and content knowledge. Contemporary Issues in Technology and Teacher Education, 9(1), 25-45.

Hechter, R. P. (2012). Pre-service teachers' maturing perceptions of a TPACK-framed signature pedagogy in science education. Computers in the Schools, 29, 53-69.

Irmak, M., \& Yilmaz-Tüzün, Ö. (2019). Investigating pre-service science teachers perceived technological pedagogical content knowledge (TPACK) regarding genetics. Research in Science \& Technological Education, 37(2), 127-146.

Jang, S. J. (2010). Integrating the interactive whiteboard and peer coaching to develop the TPACK of secondary science teachers. Computers \& Education, 55, 1744-1751.

Jang, S. J., \& Chen, K. C. (2010). From PCK to TPACK: Developing a transformative model for pre-service science teachers. Journal of Science Education Technologies, 19, 553-564.

Jen, T. H., Yeh, Y. F., Hsu, Y. S., Wu, H. K., \& Chen, K. M. (2016). Science teachers' TPACK-Practical: Standard-setting using an evidence-based approach. Computers \& Education, 95, 45-62.

Koh, J. H. L. (2013). A rubric for assessing teachers' lesson activities with respect to TPACK for meaningful learning with ICT. Australasian Journal of Educational Technology, 29(6), 887-900.

Koh, J. H. L., \& Divaharan, S. (2011). Developing pre-service teachers' technology integration expertise through the TPACK-developing instructional model. Journal of Educational Computing Research, 44(1), 35-58.

Koh, J. H. L., Chai, C. S., \& Lim, W. Y. (2017). Teacher professional development for TPACK-21CL: Effects on teacher ICT integration and student outcomes. Journal of Educational Computing Research, 55(2), 172-196.

Koehler, M., \& Mishra, P. (2009). What is technological pedagogical content knowledge (TPACK)? Contemporary Issues in Technology and Teacher Education, 9(1), 60-70.

Lee, M. H., \& Tsai, C. C. (2010). Exploring teachers' perceived selfefficacy and technological pedagogical content knowledge with respect to educational use of the World Wide Web. Instructional Science, 38(1), 1-21.
Lee, C. J., \& Kim, C. M. (2014). An implementation study of a TPACK-based instructional design model in a technology integration course. Education Technology Research Development, 62, 437-460.

Lin, T. C., Tsai, C. C., Chai, C. S., \& Lee, M. H. (2013). Identifying science teachers' perceptions of technological pedagogical and content knowledge (TPACK). Journal of Science Educational Technologies, 22, 325-336.

Lu, L., \& Lei, J. (2012). Using live dual modeling to help preservice teachers develop TPACK. Journal of Digital Learning in Teacher Education, 29(1), 14-22.

Maeng, J. L., Mulvey, B. K., Smetana, L. K., \& Bell, R. L. (2013) Preservice teachers' TPACK: using technology to support inquiry instruction. Journal of Science Educational Technologies, 22, 838-857.

Mishra, P., \& Koehler, M. J. (2006). Technological pedagogical content knowledge: A new framework for teacher knowledge. Teachers College Record, 108(6), 1017-1054.

Niess, M. L. (2005). Preparing teachers to teach science and mathematics with technology: Developing a technology pedagogical content knowledge. Teaching and Teacher Education, 21, $509-523$.

Niess, M. L. (2011). Investigating TPACK: Knowledge growth in teaching with technology. Journal of Educational Computing Research, 44(3), 299-317.

Niess, M. L., Ronau, R. N., Shafer, K. G., Driskell, S. O., Harper, S. R., Johnston, C., et al. (2009). Mathematics teacher TPACK standards and development model. Contemporary Issues in Technology and Teacher Education, 9(1), 4-24.

Özgün-Koca, S. A., Meagher, M., \& Edwards, M. T. (2011). A teacher's journey with a new generation handheld: Decisions, struggles, and accomplishments. School Science and Mathematics, 111(5), 201-224.

Redmond, P., \& Lock, J. (2019). Secondary pre-service teachers' perceptions of technological pedagogical content knowledge (TPACK): What do they really think? Australasian Journal of Educational Technology, 35(3), 45-54.

Schmidt, D. A., Baran, E., Thompson, A. D., Mishra, P., Koehler, M. J., \& Shin, T. S. (2009). Technological pedagogical content knowledge (TPACK) the development and validation of an assessment instrument for preservice teachers. Journal of Research on Technology in Education., 42(2), 123-149.

Swallow, M. J. C., \& Olofson, M. W. (2017). Contextual understandings in the TPACK framework. Journal of Research on Technology in Education, 49(3-4), 228-244.

Tokmak, H. S. (2013). Changing preschool teacher candidates' perceptions about technology integration in a TPACK-based material design course. Education as Change, 17(1), 115-129.

Toledo, C. (2005). A five-stage model of computer technology integration into teacher education curriculum. Contemporary Issues in Technology and Teacher Education, 5(2), 177-191.

Tondeur, J., Scherer, R., Siddiq, F., \& Baran, E. (2017). A comprehensive investigation of TPACK within pre-service teachers' ICT profiles: Mind the gap. Australasian Journal of Educational Technology, 33(3), 46-60.

Tondeur, J., Aesaert, K., Prestridge, S., \& Consuegra, E. (2018). A multilevel analysis of what matters in the training of pre-service teacher's ICT competencies. Computers \& Education, 122, 32-42.

Tondeur, J., Scherer, R., Baran, E., Siddiq, F., Valtonen, T., \& Sointu, E. (2019a). Teacher educators as gatekeepers: Preparing the next generation of teachers for technology integration in education. British Journal of Educational Technology, 50, 1189-1209.

Tondeur, J., Scherer, R., Siddiq, F., \& Baran, E. (2019b). Enhancing pre-service teachers' technological pedagogical content knowledge (TPACK): A mixed-method study. Educational Technology Research and Development, 68(1), 319-343. 
Tseng, J. J., Cheng, Y. S., \& Yeh, H. N. (2019). How pre-service English teachers enact TPACK in the context of web-conferencing teaching: A design thinking approach. Computers \& Education, $128,171-182$.

Wang, Q. (2008). A generic model for guiding the integration of ICT into teaching and learning. Innovations in Education and Teaching International, 45(4), 411-419.

Wang, Q., \& Woo, H. L. (2007). Systematic planning for ICT integration in topic learning. Educational Technology \& Society, 10(1), $148-156$.

Valtonen, T., Kukkonen, J., Kontkanen, S., Sormunen, K., Dillon, P., \& Sointu, E. (2015). The impact of authentic learning experiences with ICT on pre-service teachers' intentions to use ICT for teaching and learning. Computers \& Education, 81, 49-58.

Vanderlinde, R., \& Van Braak, J. (2010). The e-capacity of primary schools: Development of a conceptual model and scale construction from a school improvement perspective. Computers \& Education, 55(2), 541-553.

Voogt, J., Fisser, P., Roblin, N. P., Tondeur, J., \& van Braak, J. (2013). Technological pedagogical content knowledge-A review of the literature. Journal of Computer Assisted Learning, 29(2), 109-121.

Yeh, Y. F., Hsu, Y. S., Wu, H. K., Hwang, F. K., \& Lin, T. C. (2014). Developing and validating technological pedagogical content knowledge-practical (TPACK-practical) through the Delphi survey technique. British Journal of Educational Technology, 45(4), 707-722.

Yeh, Y. F., Lin, T. C., Hsu, Y. S., Wu, H. K., \& Hwang, F. K. (2015). Science teachers' proficiency levels and patterns of TPACK in a practical context. Journal of Science Education and Technology, 24(1), 78-90.

Yeh, Y. F., Hsu, Y., Wu, H., \& Chien, S. (2017). Exploring the structure of TPACK with video-embedded and discipline-focused assessments. Computers \& Education, 104, 49-64.

Publisher's Note Springer Nature remains neutral with regard to jurisdictional claims in published maps and institutional affiliations. 